\title{
PENERAPAN METODE LEARNING VECTOR QUANTIZATION PADA PREDIKSI INTENSITAS CURAH HUJAN DI KOTA PONTIANAK
}

\author{
Ilham Saputra, Setyo Wira Rizki
}

\begin{abstract}
INTISARI
Cuaca merupakan suatu kondisi udara di suatu wilayah atau tempat pada waktu yang relatif singkat. Keadaan cuaca yang tidak menentu tersebut merupakan hal yang mendasari perlunya untuk meramalkan cuaca. Peramalan dapat dilakukan untuk mengetahui kapan suatu peristiwa akan terjadi sehingga tindakan yang tepat dapat dilakukan. Salah satunya adalah dengan menggunakan jaringan syaraf tiruan. Jaringan syaraf tiruan adalah salah satu kecerdasan buatan yang menyerupai sistem syaraf dari otak manusia. Proses dengan menggunakan jaringan syaraf tiruan ini bertujuan untuk penerapan metode learning vector quantization pada prediksi intensitas curah hujan di Kota Pontianak. Data yang digunakan dalam penelitian ini adalah data sekunder yang diperoleh dari BMKG Pontianak. Data tersebut merupakan data curah hujan, kelembapan udara, temperatur maksimum dan temperatur minimum. Proses pelatihan pada metode learning vector quantization ini dengan menentukan bobot awal dan parameter yang digunakan. Selanjutnya melakukan pelatihan dari epoch ke-1 pada data ke-1 sampai data ke-n dan diperoleh bobot akhir. Selanjutnya mengurangi nilai alfa: $\hat{\alpha}=\alpha-$ Dec $\alpha * \alpha$. Lakukan cara yang sama pada epoch ke-2 sampai max epoch dan memperoleh bobot akhir. Bobot akhir ini akan digunakan untuk melakukan proses pengujian. Hasil pengujian dengan menggunakan jaringan syaraf tiruan menggunakan metode learning vector quantization diperoleh untuk Maksimum epoch (MaxEpoch) $=5$, learning rate $(\alpha)=0,4$, Decrease learning rate $($ Dec $\alpha)=0,1$, dan Minimum learning rate $(\operatorname{Min} \alpha)=$ 0 dengan tingkat akurasinya sebesar $90 \%$.
\end{abstract}

Kata Kunci: Jaringan Syaraf Tiruan,Cuaca, Epoch.

\section{PENDAHULUAN}

Cuaca merupakan suatu kondisi udara di suatu wilayah atau tempat pada waktu yang relatif singkat [1]. Keadaan cuaca yang tidak menentu tersebut merupakan hal yang mendasari perlunya untuk meramalkan cuaca. Informasi tentang peramalan cuaca yang cepat dan tepat menjadi kebutuhan utama yang tidak dapat dipisahkan dari aktifitas manusia dan mempengaruhi di berbagai bidang. Bidangbidang yang dapat memperngaruhi cuaca pada suatu hari seperti transportasi, pertanian atau olah raga sekalipun. Misalkan kapan waktu yang baik untuk keberangkatan pesawat terbang, kapan waktu yang baik untuk bercocok tanam dan bahkan penentuan waktu untuk pertandingan sepak bola sekalipun.

Peramalan dapat dilakukan untuk mengetahui kapan suatu peristiwa akan terjadi sehingga tindakan yang tepat dapat dilakukan. Peramalan memiliki banyak metode yang tersedia dan beragam dalam hal ketepatan. Salah satunya adalah dengan mengunakan metode learning vector quantization (LVQ). LVQ merupakan suatu metode untuk melakukan pelatihan terhadap lapisan-lapisan kompetitif yang terawasi. Lapisan kompetitif akan belajar secara otomatis untuk melakukan klasifikasi terhadap vektor input yang diberikan. Apabila beberapa vektor input memiliki jarak yang sangat berdekatan, maka vektor-vektor tersebut akan dikelompokkan dalam kelas yang sama [2]. Oleh karena itu, tujuan pada penelitian ini adalah penerapan metode LVQ pada prediksi intensitas curah hujan di Kota Pontianak. Data yang digunakan untuk prediksi intensitas curah hujan adalah data curah hujan, kelembapan udara, temperatur maksimum dan temperatur minimum. Data yang digunakan adalah data harian dari tanggal 01 Agustus 2017 sampai dengan tanggal 29 September 2017. Data hasil peramalan terbagi menjadi 5 kelas yaitu kelas 1 hujan sangat ringan, kelas 2 hujan ringan, kelas 3 hujan normal, kelas 4 hujan lebat dan kelas 5 hujan sangat lebat. Hasil prediksi hanya berlaku untuk wilayah Kota Pontianak. Metode yang digunakan adalah Learning Vector Quantization (LVQ). 
Proses pengerjaan metode LVQ ini terbagi menjadi 2 yaitu proses pelatihan dan proses pengujian. Proses pelatihan ini dilakukan dengan menentukan bobot awal dan parameter yang akan digunakan. Selanjutnya melakukan pelatihan dari epoch ke-1 pada data ke-1 sampai data ke-n dan diperoleh bobot akhir. Selanjutnya mengurangi nilai alfa: $\alpha^{*}=\alpha-\operatorname{Dec} \alpha * \alpha$. Lakukan cara yang sama pada epoch ke-2 sampai max epoch dan memperoleh bobot akhir. Setelah memperoleh bobot akhir pada proses pelatihan, bobot akhir ini digunakan untuk melakukan proses pengujian. Hasil pengujian dengan menggunakan jaringan syaraf tiruan menggunakan metode learning vector quantization diperoleh untuk Maksimum epoch (MaxEpoch) $=5$, learning rate $(\alpha)=0,4$, Decrease learning rate $(\operatorname{Dec} \alpha)=0,1$, dan Minimum learning rate $(\operatorname{Min} \alpha)=0$ dengan tingkat akurasinya sebesar $90 \%$.

\section{ARSITEKTUR JARINGAN}

Umumnya neuron-neuron yang terletak pada lapisan yang sama akan memiliki keadaan yang sama. Faktor terpenting dalam menentukan kelakuan suatu neuron adalah fungsi aktivasi dan pola bobotnya. Pada setiap lapisan yang sama, neuron-neuron akan memiliki fungsi aktivasi yang sama. Apabila neuron-neuron dalam suatu lapisan (misalkan lapisan tersembunyi) akan berhubungan dengan neuronneuron pada lapisan yang lain (misalkan lapisan output), maka setiap neuron pada lapisan tersembunyi juga berhubungan dengan setiap neuron pada lapisan lapisan output. Ada beberapa arsitektur jaringan syaraf, antara lain [3]:

1. Jaringan dengan lapisan tunggal (single layer net)

Jaringan dengan lapisan tunggal hanya memiliki satu lapisan dengan bobot-bobot yang berhubungan. Jaringan ini hanya menerima input kemudia secara langsung akan mengolahnya menjadi output tanpa harus melalui lapisan tersembunyi yang dapat dilihat pada Gambar 1 . Pada Gambar 1 tersebut, lapisan input memiliki 3 neuron yaitu $x_{1}, x_{2}$ dan $x_{3}$. Sedangkan pada lapisan output memiliki 2 neuron yaitu $y_{1}$ dan $y_{2}$. Neuron-neuron pada kedua lapisan saling berhubungan. Seberapa besar hubungan antara 2 neuron ditentukan oleh bobot yang bersesuaian. Semua unit input akan dihubungkan dengan setiap unit output [3].

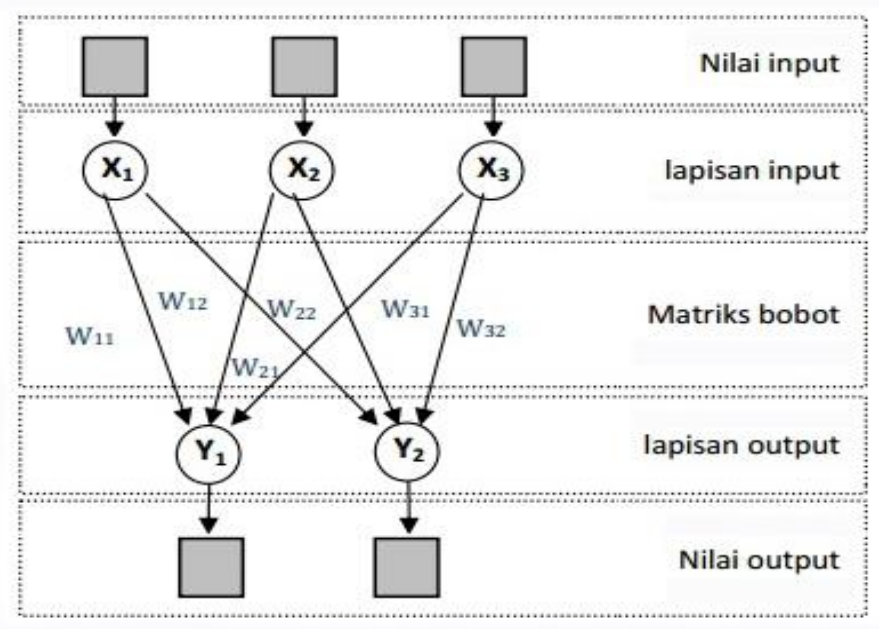

Gambar 1 Jaringan Syaraf dengan Lapisan Tunggal.

\section{Jaringan dengan banyak lapisan (multilayer net)}

Jaringan dengan banyak lapisan memiliki 1 atau lebih lapisan tersembunyi yang terletak diantara lapisan input dan lapisan output yang dapat dilihat pada Gambar 2. Jaringan dengan banyak lapisan ini dapat menyelesaikan permasalahan yang lebih sulit dari pada dengan lapisan tunggal. Tentu saja dengan pembelajaran yang lebih rumit. Namun demikian, pada banyak kasus pembelajaran pada jaringan dengan banyak lapisan ini lebih sukses dalam menyelesaikan masalah [3]. 


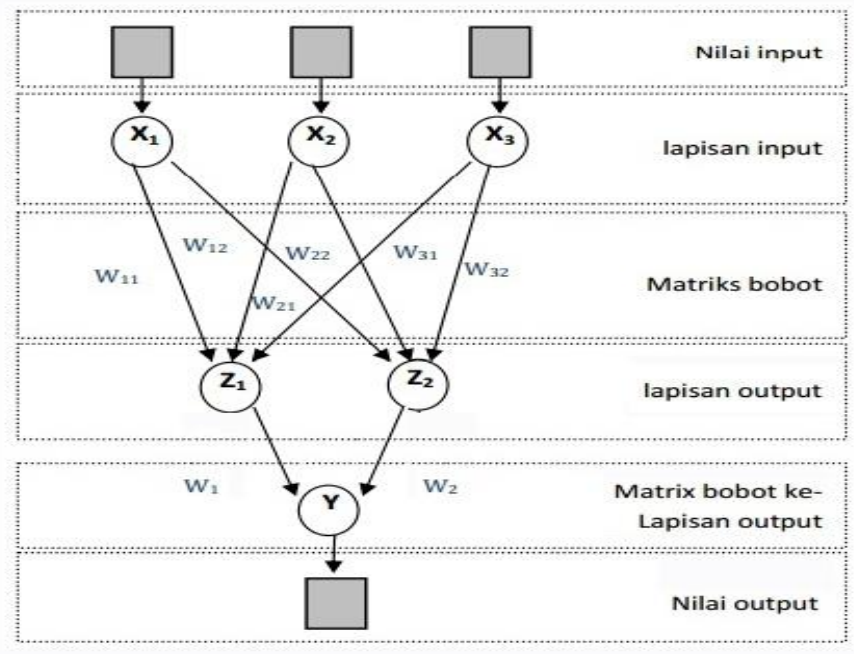

Gambar 2 Jaringan Syaraf dengan Banyak Lapisan.

3. Jaringan dengan lapisan kompetitif (competitive layer net)

Hubungan antara neuron pada lapisan kompetitif ini tidak diperlihatkan pada diagram arsitektur. Salah satu contoh arsitektur jaringan dengan lapisan kompetitif yang memiliki bobot $-\eta$ yang dapat dilihat pada Gambar 3 [3].

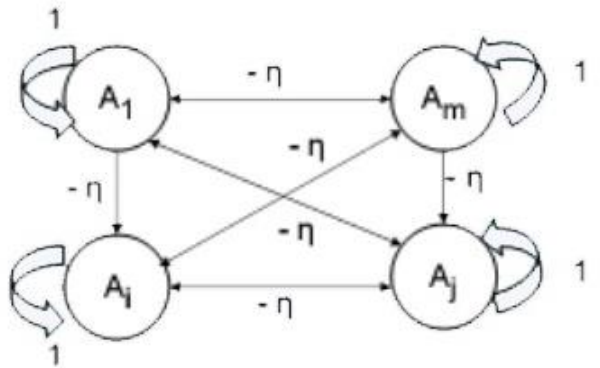

Gambar 3 Jaringan syaraf dengan lapisan kompetitif.

\section{INISIALISASI ACAK}

Prosedur yang umum dilakukan adalah menginisialisasi bias dan bobot. Baik dari unit input ke unit tersembunyi maupun dari unit tersembunyi ke unit output ke dalam sebuah interval tertentu $(-\gamma$ dan $\gamma)$. Misalkan antara $-0,4$ sampai $0,4,-0,5$ sampai 0,5 , dan -1 sampai 1 [4].

\section{LAMA ITERASI}

Tujuan utama pada jaringan syaraf tiruan adalah mendapatkan keseimbangan antara pengenalan pola data pelatihan secara benar dan respon yang baik untuk pola data pengujian. Jaringan dapat dilatih terus menerus sehingga semua pola data pelatihan dikenali dengan benar. Akan tetapi hal itu tidak menjamin jaringan akan mampu mengenali pola data pengujian dengan tepat. Jadi tidaklah bermanfaat untuk meneruskan iterasi sehingga semua kesalahan pola data pelatihan $=0$ [5].

\section{METODE LEARNING VECTOR QUANTIZATION (LVQ)}

Metode learning vector quantization ( $L V Q)$ merupakan suatu metode untuk melakukan pelatihan terhadap lapisan-lapisan kompetitif yang terawasi. Lapisan kompetitif akan belajar secara otomatis untuk melakukan klasifikasi terhadap vektor input yang diberikan. Apabila beberapa vektor input memiliki jarak yang sangat berdekatan, maka vektor-vektor tersebut akan dikelompokkan dalam kelas yang sama. Pada Gambar 4 menunjukkan jaringan LVQ dengan 6 unit pada lapisan input dan 2 unit pada lapisan output. Pemrosesan yang terjadi pada setiap neuron adalah mencari jarak antara 
suatu vektor input ke bobot yang bersangkutan $\mathrm{w}_{1}$ dan $\mathrm{w}_{2} . \mathrm{w}_{1}$ adalah vektor bobot yang menghubungkan setiap neuron pada lapisan input ke neuron pertama pada lapisan output. Sedangkan $\mathrm{w}_{2}$ adalah vector bobot yang menghubungkan setiap neuron pada lapisan input ke neuron kedua pada lapisan output. Fungsi aktivasi $\mathrm{F}_{1}$ akan memetakan $\mathrm{y}_{-} \mathrm{in}_{1}$ ke $\mathrm{y}_{1}=1$ apabila $\left\|\mathrm{x}-\mathrm{w}_{1}\right\|<\left\|\mathrm{x}-\mathrm{w}_{2}\right\|$.

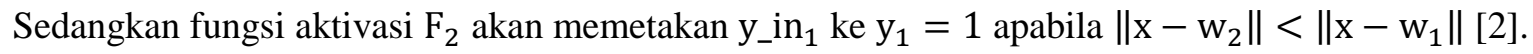

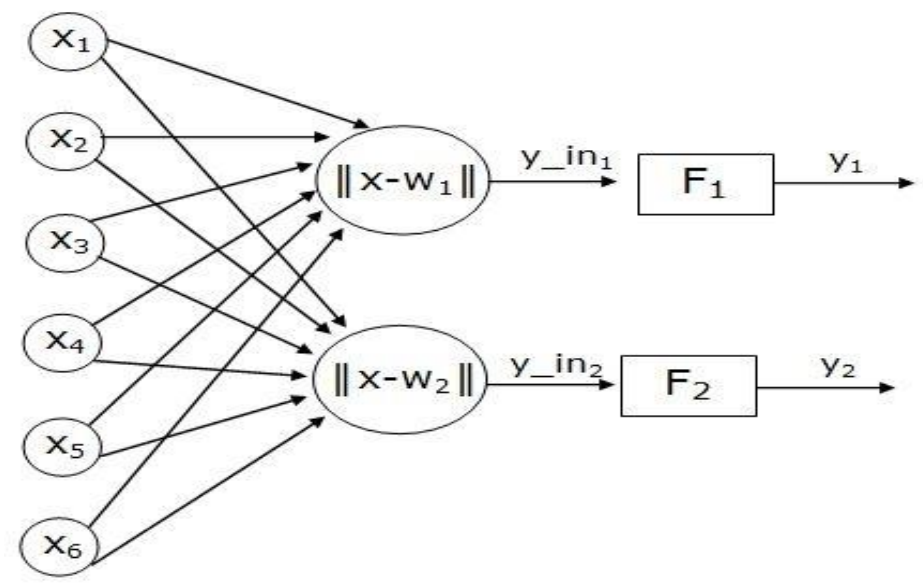

Gambar 4 Arsitektur Jaringan Learning Vector Quantization (LVQ).

\section{STUDI KASUS}

Data yang digunakan dalam penelitian ini adalah data sekunder yang diperoleh dari BMKG Pontianak. Data tersebut merupakan data harian curah hujan (mm), kelembapan udara (\%), temperatur maksimum $\left({ }^{\circ} \mathrm{C}\right)$, dan temperatur minimum $\left({ }^{\circ} \mathrm{C}\right)$. Data tersebut dibagi menjadi 2 yaitu data pelatihan dan data pengujian. Data pelatihan dari tanggal 01 Agustus 2017 sampai dengan tanggal 09 September 2017. Sedangkan data pengujian dari tanggal 10 September 2017 sampai dengan tanggal 29 September 2017.
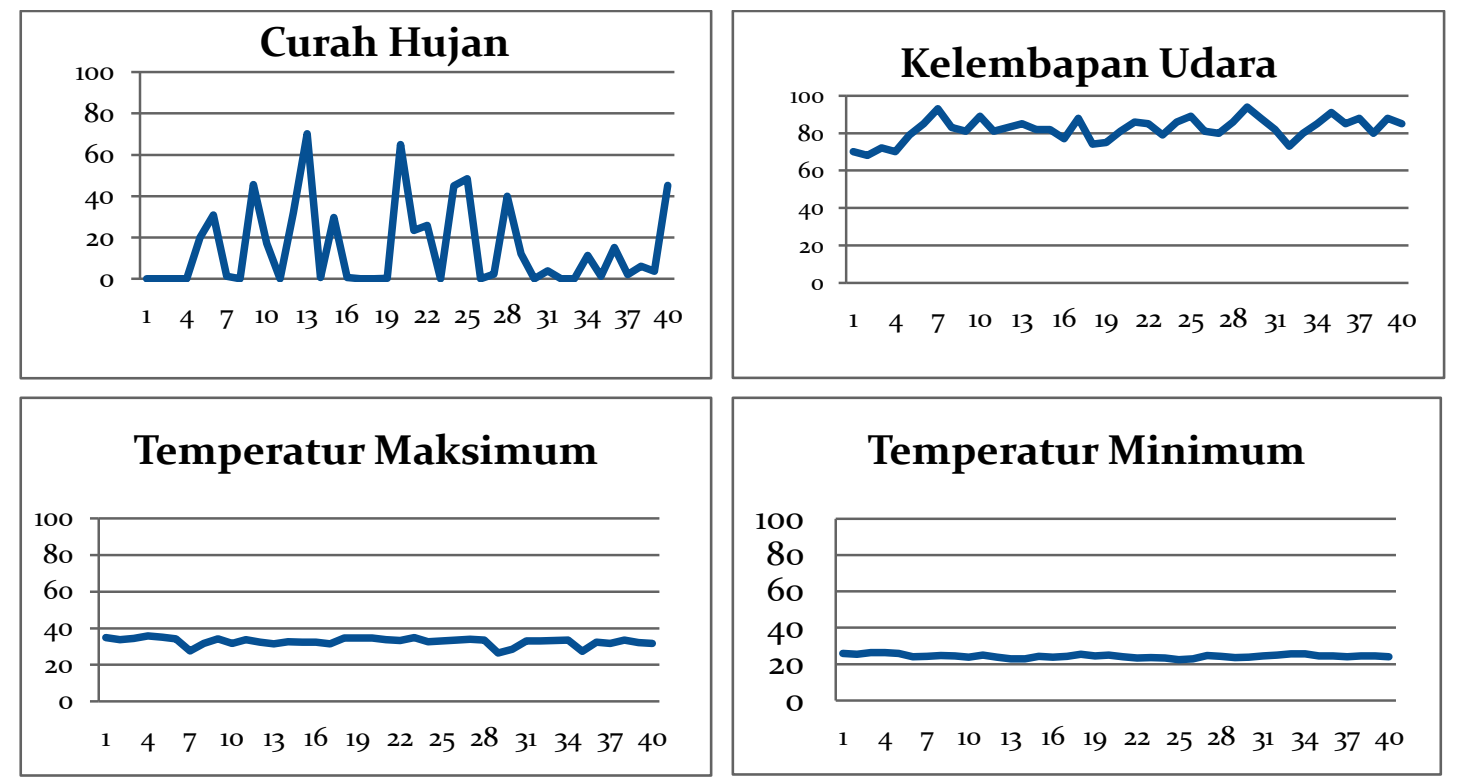

Gambar 5 Data Curah Hujan (mm), Kelembapan Udara (\%), Temperatur Maksimum $\left({ }^{\circ} \mathrm{C}\right)$ dan Temperatur Minimum $\left({ }^{\circ} \mathrm{C}\right)$.

Grafik data pada Gambar 5 menunjukkan data harian curah hujan, kelembapan udara, teperatur maksimum dan temperatur minimum memiliki pola stasioner di mana data tersebut mengalami kenaikan atau penurunan secara konsisten. 


\section{PROSES PELATIHAN DENGAN METODE LEARNING VECTOR QUANTIZATION (LVQ)}

Variabel yang terlibat dalam meramalkan cuaca pada penelitian ini meliputi 4 variabel yaitu curah hujan, kelembapan udara, temperatur maksimum dan temperatur minimum, dimisalkan sebagai berikut:

$\mathrm{x}_{1}=$ Curah Hujan $(\mathrm{mm})$

$\mathrm{x}_{2}=$ Kelembapan Udara $(\%)$

$\mathrm{x}_{3}=$ Temperatur Maksimum $\left({ }^{\circ} \mathrm{C}\right)$

$\mathrm{x}_{4}=$ Temperatur Minimum $\left({ }^{\circ} \mathrm{C}\right)$

$\mathrm{T}=$ Target dalam bentuk kelas.

Percobaan ke 1:

Langkah 1: Membuat arsitektur jaringan Learning Vector Quantization dengan 2 lapisan. Lapisan ke 1 yaitu lapisan input yang terdiri dari 4 neuron dan lapisan ke 2 yaitu lapisan output yang terdiri dari 4 neuron. Arsitektur jaringan Learning Vector Quantization disajikan pada Gambar 6 berikut:

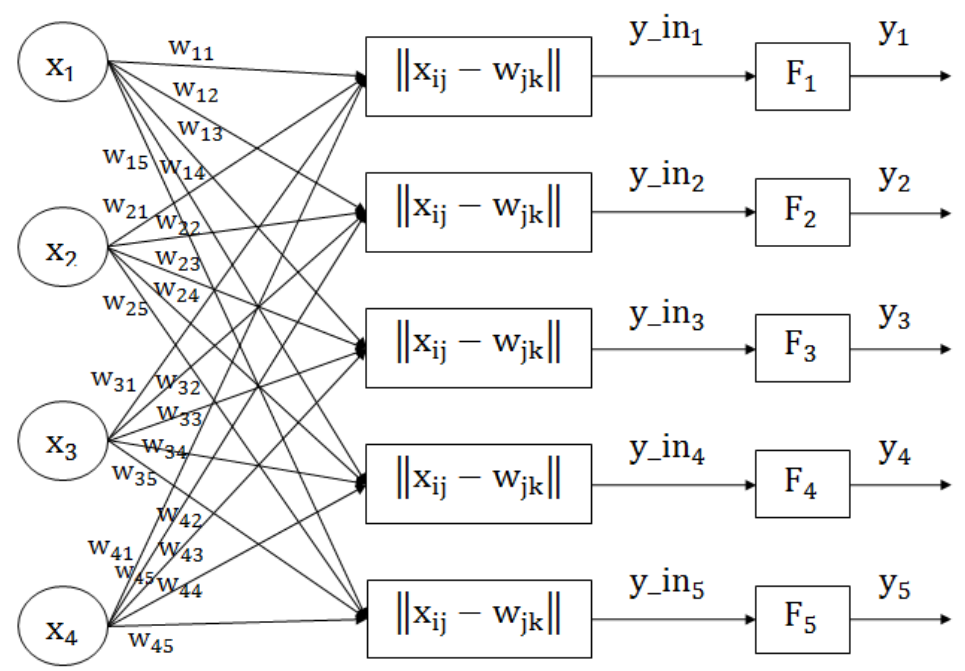

Gambar 6 Arsitektur Jaringan Learning Vector Quantization (LVQ).

Langkah 2: Penentuan bobot awal lapisan input $x_{i j}$ ke lapisan output secara acak:

$\begin{array}{llll}\mathrm{w}_{11}=30,54 & \mathrm{w}_{21}=78,43 & \mathrm{w}_{31}=32,62 & \mathrm{w}_{41}=24,68 \\ \mathrm{w}_{12}=34,89 & \mathrm{w}_{22}=80,87 & \mathrm{w}_{32}=30,99 & \mathrm{w}_{42}=24,41 \\ \mathrm{w}_{13}=33,18 & \mathrm{w}_{23}=81,82 & \mathrm{w}_{33}=31,65 & \mathrm{w}_{43}=24,29 \\ \mathrm{w}_{14}=43,70 & \mathrm{w}_{24}=83,39 & \mathrm{w}_{34}=32,12 & \mathrm{w}_{44}=24,04 \\ \mathrm{w}_{15}=42,30 & \mathrm{w}_{25}=84,49 & \mathrm{w}_{35}=33,55 & \mathrm{w}_{45}=24,15\end{array}$

Langkah 3: Penetapan parameter-parameter yang digunakan dalam pelatihan yaitu sebagai berikut:

Maksimum epoch $($ MaxEpoch $)=5$

Parameter learning rate $(\alpha)=0,4$

Pengurangan learning rate $($ Dec $\alpha)=0,1$

Minimum learning rate $($ Min $\alpha)=0$

Langkah 4: Melakukan pelatihan dengan epoch ke 1:

Data pelatihan ke 1: $\left(\begin{array}{llll}0 & 70 & 34,8 & 25,9\end{array}\right)$

Menghitung jarak data pelatihan ke 1 pada:

bobot kelas ke-1 $\left\|\mathrm{x}_{\mathrm{ij}}-\mathrm{w}_{\mathrm{j} 1}\right\|$

$=\sqrt{(0-30,54)^{2}+(70-78,43)^{2}+(34,8-32,62)^{2}+(25,9-24,68)^{2}}=31,780$ 
bobot kelas ke-2 $\left\|\mathrm{x}_{\mathrm{ij}}-\mathrm{w}_{\mathrm{j} 2}\right\|$

$=\sqrt{(0-34,89)^{2}+(70-80,87)^{2}+(34,8-30,99)^{2}+(25,9-24,41)^{2}}=36,772$

bobot kelas ke-3 $\left\|\mathrm{x}_{\mathrm{ij}}-\mathrm{w}_{\mathrm{j} 3}\right\|$

$=\sqrt{(0-33,18)^{2}+(70-81,82)^{2}+(34,8-31,65)^{2}+(25,9-24,29)^{2}}=35,400$

bobot kelas ke-4 $\left\|\mathrm{x}_{\mathrm{ij}}-\mathrm{w}_{\mathrm{j} 4}\right\|$

$=\sqrt{(0-43,70)^{2}+(70-83,39)^{2}+(34,8-32,12)^{2}+(25,9-24,04)^{2}}=45,822$

bobot kelas ke-5 $\left\|\mathrm{x}_{\mathrm{ij}}-\mathrm{w}_{\mathrm{j} 5}\right\|$

$=\sqrt{(0-42,30)^{2}+(70-84,49)^{2}+(34,8-33,55)^{2}+(25,9-24,15)^{2}}=44,765$

Jarak terkecil pada bobot kelas ke 1

Target data pelatihan ke-1 $\left(\mathrm{T}_{\mathrm{i}}\right)=1$

Perbaiki bobot kelas ke-1:

$\mathrm{w}_{11}=\mathrm{w}_{11}+\alpha *\left(\mathrm{x}_{11}-\mathrm{w}_{11}\right)=30,54+0,4 *(0-30,54)=18,324$

$\mathrm{w}_{21}=\mathrm{w}_{21}+\alpha *\left(\mathrm{x}_{12}-\mathrm{w}_{21}\right)=78,43+0,4 *(70-78,43)=75,058$

$\mathrm{w}_{31}=\mathrm{w}_{31}+\alpha *\left(\mathrm{x}_{13}-\mathrm{w}_{31}\right)=32,62+0,4 *(34,8-32,62)=33,492$

$\mathrm{w}_{41}=\mathrm{w}_{41}+\alpha *\left(\mathrm{x}_{14}-\mathrm{w}_{41}\right)=24,68+0,4 *(25,9-24,68)=25,168$

Jadi bobot kelas ke 1 baru:

$\mathrm{w}_{\mathrm{j} 1}=(18,32475,05833,492 \quad 25,168)$

Proses tersebut diteruskan untuk data pelatihan ke 2 sampai data pelatihan ke 40 di epoch ke 1, maka diperoleh bobot akhir di epoch ke 1:

$\begin{array}{llll}\mathrm{w}_{11}=-0,43 & \mathrm{w}_{21}=86,86 & \mathrm{w}_{31}=31,06 & \mathrm{w}_{41}=24,40 \\ \mathrm{w}_{12}=38,14 & \mathrm{w}_{22}=77,70 & \mathrm{w}_{32}=28,68 & \mathrm{w}_{42}=24,92 \\ \mathrm{w}_{13}=33,83 & \mathrm{w}_{23}=84,11 & \mathrm{w}_{33}=32,75 & \mathrm{w}_{43}=23,35 \\ \mathrm{w}_{14}=58,28 & \mathrm{w}_{24}=83,16 & \mathrm{w}_{34}=32,64 & \mathrm{w}_{44}=24,00 \\ \mathrm{w}_{15}=34,56 & \mathrm{w}_{25}=78,25 & \mathrm{w}_{35}=35,78 & \mathrm{w}_{45}=26,38\end{array}$

Pengurangan nilai alfa $(\alpha)$ :

$\widehat{\alpha}=\alpha-\alpha * \operatorname{Dec} \alpha$

$$
=0,02-0,02 * 0,1=0,018
$$

Lakukan proses yang sama untuk epoch ke 2 sampai max epoch yaitu epoch ke 5, untuk setiap data dengan menggunakan cara yang sama. Setelah di epoch yang ke 5 maka diperoleh bobot akhir:

$\begin{array}{llll}\mathrm{w}_{11}=0,87 & \mathrm{w}_{21}=85,85 & \mathrm{w}_{31}=31,30 & \mathrm{w}_{41}=24,48 \\ \mathrm{w}_{12}=14,49 & \mathrm{w}_{22}=83,43 & \mathrm{w}_{32}=30,84 & \mathrm{w}_{42}=25,46 \\ \mathrm{w}_{13}=42,08 & \mathrm{w}_{23}=85,41 & \mathrm{w}_{33}=32,68 & \mathrm{w}_{43}=23,75 \\ \mathrm{w}_{14}=67,34 & \mathrm{w}_{24}=82,41 & \mathrm{w}_{34}=33,24 & \mathrm{w}_{44}=24,10 \\ \mathrm{w}_{15}=36,90 & \mathrm{w}_{25}=73,61 & \mathrm{w}_{35}=37,71 & \mathrm{w}_{45}=28,42\end{array}$

PROSES PENGUJIAN DENGAN METODE LEARNING VECTOR QUANTIZATION (LVQ)

Setelah diperoleh bobot akhir pada proses pelatihan dengan metode LVQ, kemudian kita akan melakukan simulasi terhadap data pengujian. Apakah hasilnya sesuai dengan target yang sebenarnya. Data pengujian ke 1: (25,6 9729 24,2) 
Menghitung jarak data pengujian ke 1 pada:

Bobot kelas ke $1\left\|\mathrm{x}_{\mathrm{ij}}-\mathrm{w}_{\mathrm{j} 1}\right\|$

$=\sqrt{(25,6-0,87)^{2}+(97-85,85)^{2}+(29-31,30)^{2}+(24,2-24,48)^{2}}=27,182$

bobot kelas ke $2\left\|\mathrm{x}_{\mathrm{ij}}-\mathrm{w}_{\mathrm{j} 2}\right\|$

$=\sqrt{(25,6-14,49)^{2}+(97-83,43)^{2}+(29-30,84)^{2}+(24,2-25,46)^{2}}=17,585$

bobot kelas ke $3\left\|\mathrm{x}_{\mathrm{ij}}-\mathrm{w}_{\mathrm{j} 3}\right\|$

$=\sqrt{(25,6-42,08)^{2}+(97-83,41)^{2}+(29-32,68)^{2}+(24,2-23,75)^{2}}=20,417$

bobot kelas ke $4\left\|\mathrm{x}_{\mathrm{ij}}-\mathrm{w}_{\mathrm{j} 4}\right\|$

$=\sqrt{(25,6-67,34)^{2}+(97-82,41)^{2}+(29-33,24)^{2}+(24,2-24,10)^{2}}=44,378$

bobot kelas ke $5\left\|\mathrm{x}_{\mathrm{ij}}-\mathrm{w}_{\mathrm{j} 5}\right\|$

$=\sqrt{(25,6-36,90)^{2}+(97-73,61)^{2}+(29-37,71)^{2}+(24,2-28,42)^{2}}=27,620$

Jarak terkecil pada bobot kelas ke-2

Proses tersebut diteruskan untuk data pengujian ke 2 sampai data pengujian ke 20.

Tabel Hasil Pengujian.

\begin{tabular}{|c|c|c|c|c|c|c|c|c|c|c|c|c|}
\hline \multirow{2}{*}{$\begin{array}{c}\text { Data } \\
\text { ke- }\end{array}$} & \multicolumn{4}{|c|}{ Data $(\mathrm{X})$} & \multirow{3}{*}{$\mathrm{T}_{\mathrm{i}}$} & \multicolumn{5}{|c|}{ Jarak Data Pengujian ke- } & Jarak & Masuk \\
\cline { 2 - 9 } & $\mathrm{x} 1$ & $\mathrm{x} 2$ & $\mathrm{x} 3$ & $\mathrm{x} 4$ & & 1 & 2 & 3 & 4 & 5 & Terkecil & Kelas ke- \\
\hline 1 & 25,6 & 97 & 29,0 & 24,2 & 3 & 27,182 & 17,585 & 20,417 & 44,378 & 27,620 & 17,585 & $2^{*}$ \\
2 & 5,7 & 79 & 33,1 & 24,6 & 2 & 8,446 & 10,066 & 36,924 & 61,727 & 32,251 & 8,446 & $1^{*}$ \\
3 & 0,1 & 90 & 32,0 & 24,4 & 1 & 4,359 & 15,929 & 42,250 & 67,687 & 40,919 & 4,359 & 1 \\
4 & 0 & 80 & 32,9 & 24,6 & 1 & 6,484 & 15,146 & 42,484 & 67,399 & 37,889 & 6,484 & 1 \\
5 & 0 & 75 & 36,1 & 26,0 & 1 & 11,888 & 17,523 & 43,514 & 67,820 & 37,045 & 11,888 & 1 \\
6 & 0 & 76 & 36,2 & 26,8 & 1 & 11,083 & 17,101 & 43,323 & 67,741 & 37,059 & 11,083 & 1 \\
7 & 10 & 87 & 30,8 & 24,4 & 2 & 9,204 & 5,741 & 32,174 & 57,563 & 31,030 & 5,741 & 2 \\
8 & 8,8 & 89 & 30,0 & 23,4 & 2 & 8,775 & 8,397 & 33,603 & 59,023 & 33,424 & 8,397 & 2 \\
9 & 1 & 85 & 33,0 & 24,0 & 1 & 1,983 & 13,823 & 41,084 & 66,388 & 38,201 & 1,983 & 1 \\
10 & 0,3 & 83 & 32,5 & 24,6 & 1 & 3,400 & 14,329 & 41,875 & 67,045 & 38,267 & 3,400 & 1 \\
11 & 0 & 73 & 35,1 & 25,1 & 1 & 13,656 & 18,487 & 44,023 & 68,058 & 37,151 & 13,656 & 1 \\
12 & 0 & 71 & 33,6 & 25,8 & 1 & 15,031 & 19,242 & 44,510 & 68,308 & 37,307 & 15,031 & 1 \\
13 & 0 & 72 & 35,0 & 26,0 & 1 & 14,619 & 19,039 & 44,340 & 68,217 & 37,122 & 14,619 & 1 \\
14 & 0 & 76 & 33,0 & 23,3 & 1 & 9,822 & 16,442 & 43,061 & 67,622 & 37,646 & 9,822 & 1 \\
15 & 0 & 75 & 34,1 & 23,6 & 1 & 11,512 & 17,303 & 43,432 & 67,781 & 37,406 & 11,512 & 1 \\
16 & 0 & 74 & 34,6 & 25,6 & 1 & 12,560 & 17,793 & 43,730 & 67,916 & 37,139 & 12,560 & 1 \\
17 & 0,4 & 74 & 35,0 & 25,4 & 1 & 12,392 & 17,422 & 43,290 & 67,493 & 36,728 & 12,392 & 1 \\
18 & 0 & 84 & 30,6 & 25,2 & 1 & 1,920 & 14,530 & 42,167 & 67,431 & 39,247 & 1,920 & 1 \\
19 & 18,3 & 85 & 32,1 & 24,1 & 2 & 17,501 & 4,401 & 23,803 & 49,102 & 22,745 & 4,401 & 2 \\
20 & 0 & 80 & 34,6 & 24,6 & 1 & 6,425 & 15,296 & 42,428 & 67,384 & 37,843 & 6,425 & 1 \\
\hline
\end{tabular}

Keterangan * : pada data ke 1 diperoleh jarak terkecil dari data pengujian ke 1 pada bobot kelas ke 2 yaitu sebesar 17,585 yang masuk ke kelas 2 tidak sesuai dengan target aslinya $\left(\mathrm{T}_{\mathrm{i}}\right)$ yang seharusnya masuk dalam kelas ke 3 .

\section{PENUTUP}

Penulis telah melakukan beberapa kali percobaan dengan mengimplementasikan jaringan syaraf tiruan metode learning vector quantization (LVQ) untuk peramalan cuaca diperoleh hasil untuk maksimum epoch $($ MaxEpoch $)=5$, learning rate $(\alpha)=0,4$, pengurangan learning rate $($ Dec $\alpha)=0,1$, dan minimum learning rate $($ Min $\alpha)=0$ dengan tingkat keakurasi sebesar $90 \%$. 


\section{DAFTAR PUSTAKA}

[1]. Suchayono, D. S. \& Ribudiyanto, K. (2013). Cuaca dan Iklim Ekstrim di Indonesia. Jakarta: Pusat Penelitian dan Pengembangan, BMKG.

[2]. Kusumadewi, S. (2003). Artificial Intelligence (Teknik dan Aplikasinya). Yogyakarta: Graha Ilmu.

[3]. Kusumadewi, S. (2004). Membangun Jaringan Syaraf Tiruan Menggunakan MATLAB \& EXCEL LINK. Yogyakarta: Graha Ilmu.

[4]. Puspitaningrum, D. (2006). Pengantar Jaringan Syaraf Tiruan. Yogyakarta: ANDI OFFSET.

[5]. Siang, J. J. (2005). Jaringan Syaraf Tiruan dan Pemrograman Menggunakan Matlab. Yogyakarta: ANDI OFFSET.

$\begin{array}{ll}\text { ILHAM SAPUTRA } & \begin{array}{l}\text { J Jurusan Matematika FMIPA Untan, Pontianak, } \\ \text { ilham.saputra.mtk12@ gmail.com } \\ \text { : Jurusan Matematika FMIPA Untan, Pontianak, } \\ \text { setyo.wirarizki@ @math.untan.ac.id }\end{array}\end{array}$

